\title{
Campaign Props and the Political Space in Bandung
}

\author{
Lingga Agung ${ }^{1}$, Novian Denny Nugraha ${ }^{2}$ \\ \{linggaagung@telkomuniversity.ac.id ${ }^{1}$, noviandenny@telkomuniversity.ac.id $\left.{ }^{2}\right\}$ \\ Telkom University, Indonesia ${ }^{1}$ \\ Telkom University, Indonesia ${ }^{2}$
}

\begin{abstract}
Space has a very important position in the modern societies. Space becomes a 'holy grail' that contested by lots of people. Towards the Indonesia election on April, the positions of space in Bandung are very interesting to examine. The election participants from the DPR, DPD, and Provincial DPRD, City/Regency to Presidential Candidates are increasingly competing in campaigns through Alat Peraga Kampanye (Campaign props: Banners, Billboards, Posters and Sticker). Using Lefebvre's space theory, this research examines the problem of the city as a public-owned space that is dominated by certain social classes (Politician). And through the Theory of Aesthetics Jacques Ranciere, this research will examine the designs of 2019 Election participants in the campaign props. Both of them are important to examine because they are the very basis for the ideology mechanisms of production, reproduction, and construction in our society today towards the election.
\end{abstract}

Keyword: Politics, Space, Aesthetics.

\section{Introduction}

For Lefebvre, space has a very important position in the life of the modern society. Modern society consists of social classes that have their own interests in space [1]. Space becomes a kind of 'holy grail' because it has become a commodity that used by certain social classes to produce, reproduce, and construct knowledge-Foucault called it the relationship of power and knowledge. When a particular social class dominates space, a city, for example, the behavior of the citizens will slowly be exposed because of the continual mechanism of production, reproduction, and construction of the knowledge.

Space has become a warfare that raises various problems between social classes and often marginalizes social classes that do not have enough capital in this space warzone. The warzone for 'space-city' in Bandung toward the election in April is so important to study, because the 2019 Election participants starting from the Legislative Election (DPR, DPD and Provincial, City/Regency DPRD) and the President seem to compete and dominate the space through a variety of campaign props almost in every corner in the city.

This campaign props causing 'visual junk', which disrupts the aesthetics of the city. The participant didn't obey the rules by KPU. In Law No. 7 of 2017 the General Elections Members of the DPR, DPD, and DPRD: all election participants must pay attention to aesthetics in disseminating campaign material. Article 298 paragraph (2): Installation of election campaign props by the election campaign implementers as referred to in paragraph (1) shall be carried out 
by considering ethics, aesthetics, cleanliness and the beauty of the city or local area in accordance with the laws and regulations [2].

We observed the design of the campaign props 2019 election participants that conducted in several areas in Bandung. Almost every participant had a campaign props but the design that did not follow the Technical Guidelines of the KPU, besides that the designs were unattractiveeven practically awful. Good design is very important in political campaigns because it can increase the electability of participants.

Space and campaign props'-including the designs - has a very tight relationship in. A campaign prop is a producer of knowledge that has an important role in constructing political knowledge in a space. A space is a medium that perpetuates the construction of knowledge if it takes place at a certain time. Both of these things become necessary in the political context especially if they obey the rules that have been stipulated by the KPU.

However, in the political contestation in Indonesia, the totalitarian efforts to dominate and de-legitimize space are a necessary in Indonesia political culture, and this has gradually claimed public space which is actually shared property and used for the common interest rather than for certain social classes - election participants.

This research was conducted during the campaign period until April 13, 2019 in the city of Bandung. In this study, we examine how space and CAMPAIGN PROPS relations (including their designs) borrow from Lefebvre and Politic Aesthetics Ranciere's space theories. Both of them are important in understanding the current political dynamics in Indonesia, especially their relation to space and aesthetics.

\section{Research Method}

This study used qualitative research. In qualitative research, the data are classified into, (1) audio, (2) texts, (3) audio-visual data, (4) visuals, (5) artifacts, and (6) social behavior [3]. Campaign props in this study are a text- the text itself divided into two types: text as a sign system and text as a grammatical structure [3].

In this study, space and campaign props represents experience, which can be analyzed by identifying the elements that are part of a culture. Therefore, space and campaign props can be studied among elements or in other words space and campaign props analysis depart from space and campaign props as a sign system.

The data in this study are divided into two types, primary data and secondary. Primary data are visual data, such as the main roads, intersections, Bandung City Park and 56 campaign props of the election participants in the 2019. From these 56 campaign props, we select only a few campaign props because there are similar things in between.

Space and campaign props are included in texts that represent experiences that are formed from the cultural construction. Space and campaign props have relationships that cannot be separated because they are interconnected and connected in a political context in Indonesia. There is also secondary data used in this study is a variety of literature that examines about space, city, politics, and aesthetics. 


\section{Results and Discussion}

\subsection{Space and Politic}

According to Lefebvre, space is produced by human social actions that give meaning to it. In space production, Lefebvre stated that there are 3 sets of spaces which are often referred as A Conceptual Triad of Social Space Production: (1) Spatial practice refers to the production and reproduction of spatial relations between objects and products, (2) Space representation that depends on patterns production relations and order aimed at imposing a certain pattern of relations for the use of a space, and (3) Representational space that refers to space that is real life and is directly related to various forms of imaging and symbols associated with it [4].

The placement of campaign props in Bandung has produced, reproduced, and constructed political knowledge that is too dominant and tend to be hegemonies because it takes place in the Representational Space and Space Representations or spaces that are perceived and conceptually conceptualized so as to produce, reproduce and construct knowledge from social classes which in this case are participants 2019 election.

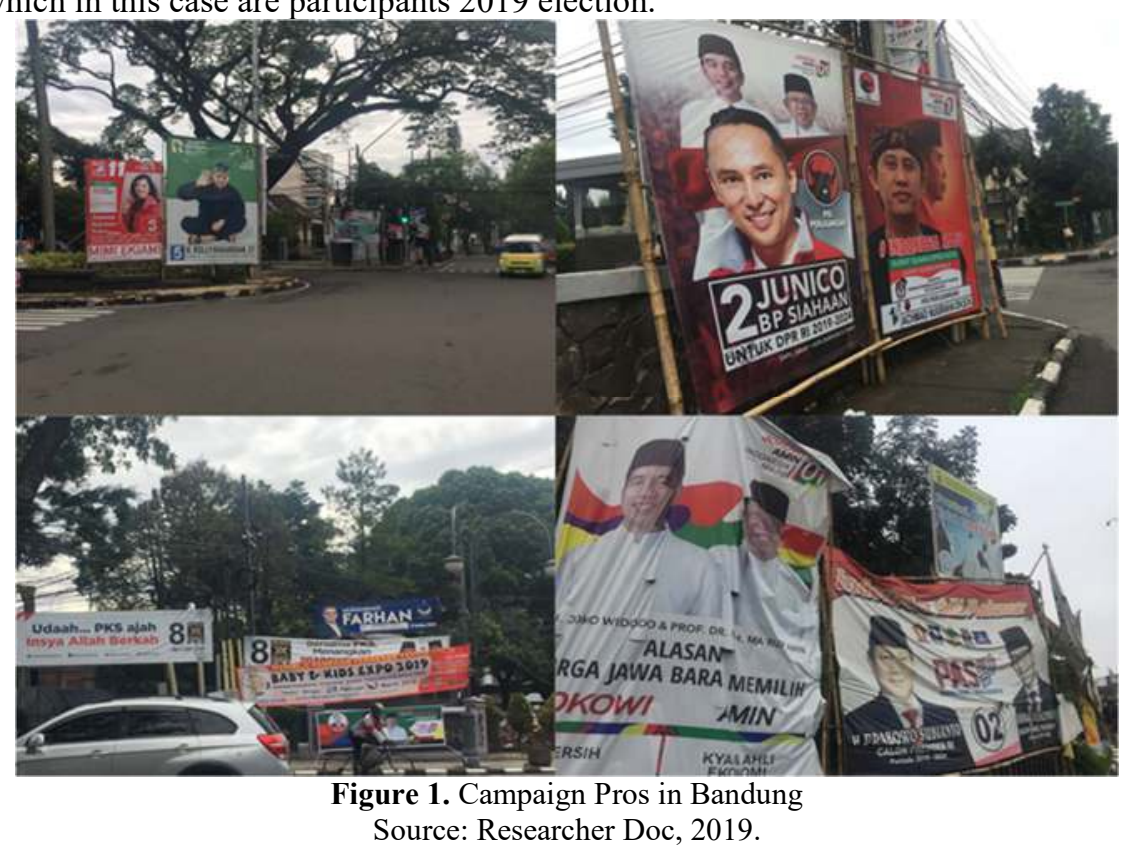

In the Space Representation, the relationship between campaign props and spaces in Bandung tends to be forced because it interrupts public-owned space-besides being dominated by the participants who have a larger capital that can be seen from the size of the campaign props. This pattern can be seen from the campaign props set up that mostly careless without conform the rules of the KPU. Thus disturbing the aesthetics of the city because some of them overlap and appear to be worn, dull, and torn in baptized weather anomalies in the city of Bandung. The campaign props of the participants form a Representational Space because it is related to the image and symbols associated with-In this case the political culture of the people in the city of Bandung. 


\subsection{Political Aesthetics}

Aesthetics plays an important role when it comes to image and symbol-also politics. Aesthetics can be understood as a science that seeks to and understand beauties. Thus, aesthetics is the knowledge of beauty [5]. According to Pierre Bourdieu, aesthetics is a mechanism of social reproduction where knowledge and tastes are distributed through regenerative systems that take place hierarchically and at the same time structure the agency (active actors) involved in the cultural reproduction field [6].

From the campaign props of the participant we know that the aesthetic mechanism has produce, reproduce, and constructed the knowledge from a certain social classis in the area of the Representational Space and Representational Space. The participant campaign props design of the 2019 Election has gone through the two space mechanisms. As a form of 'art', the design distributes human experience and expectations because quoting Ranciere, "art has a political dimension that distributes human experience and expectations." For Ranciere, every art has its own political dimension because the art itself constructing, producing, and building what is valuable for the people. This happen because there is a distribution of the sensible, which at the same time is something commonly, shared exclusively [7].

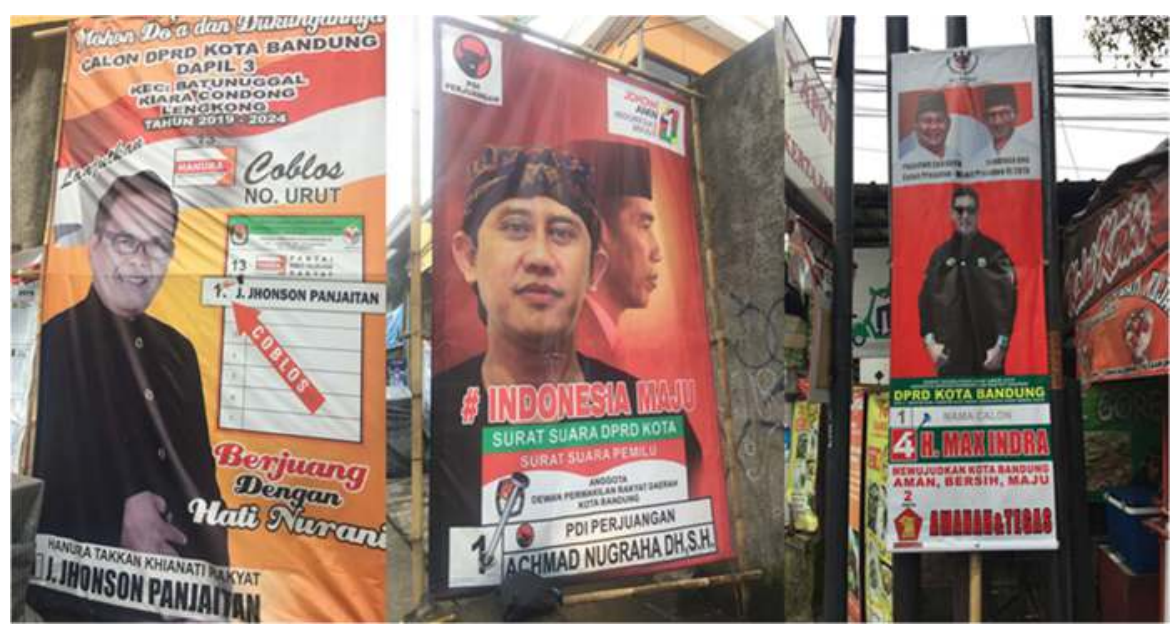

Figure 2. Campaign Pros from Hanura Party, PDI-P, and Gerindra participant in Bandung. Source: Researcher Doc, 2019.

\subsection{The Participants and The Messages}

The participants of the 2019 Election in Bandung did then not realize this: campaign props that they spread did not distribute any experiences and hopes from the people of Bandung culturally and politically. Of the three election participants, left to right: Hanura, PDI-P, and Gerindra have a less attractive design because the overlapping layout does not heed the basic principles of aesthetics, uses more than one type of font, exposes their own face and the important people behind the party (Jokowi and Prabowo), no vision and mission, and narrating something less clear like "Berjuang Dengan Hati Nurani” and "\# INDONESIA MAJU”.

There is no participant that distributes the experience and expectations of the people of Bandung. The three participants, except from PDI-P relied on his figure simply by displaying 
what he was without constructing himself as part of the Bandung people (read: Sundanese). Meanwhile from PDI-P and Gerindra, they expose presidential candidates from each of their parties. The three campaign props did not include clear visions because what is "Berjuang Dengan Hati Nurani" actually? And what is \# INDONESIA MAJU? These two statements were not a vision and mission but something normative and generic-even the writing \# INDONESIA MAJU was wrong all the way.

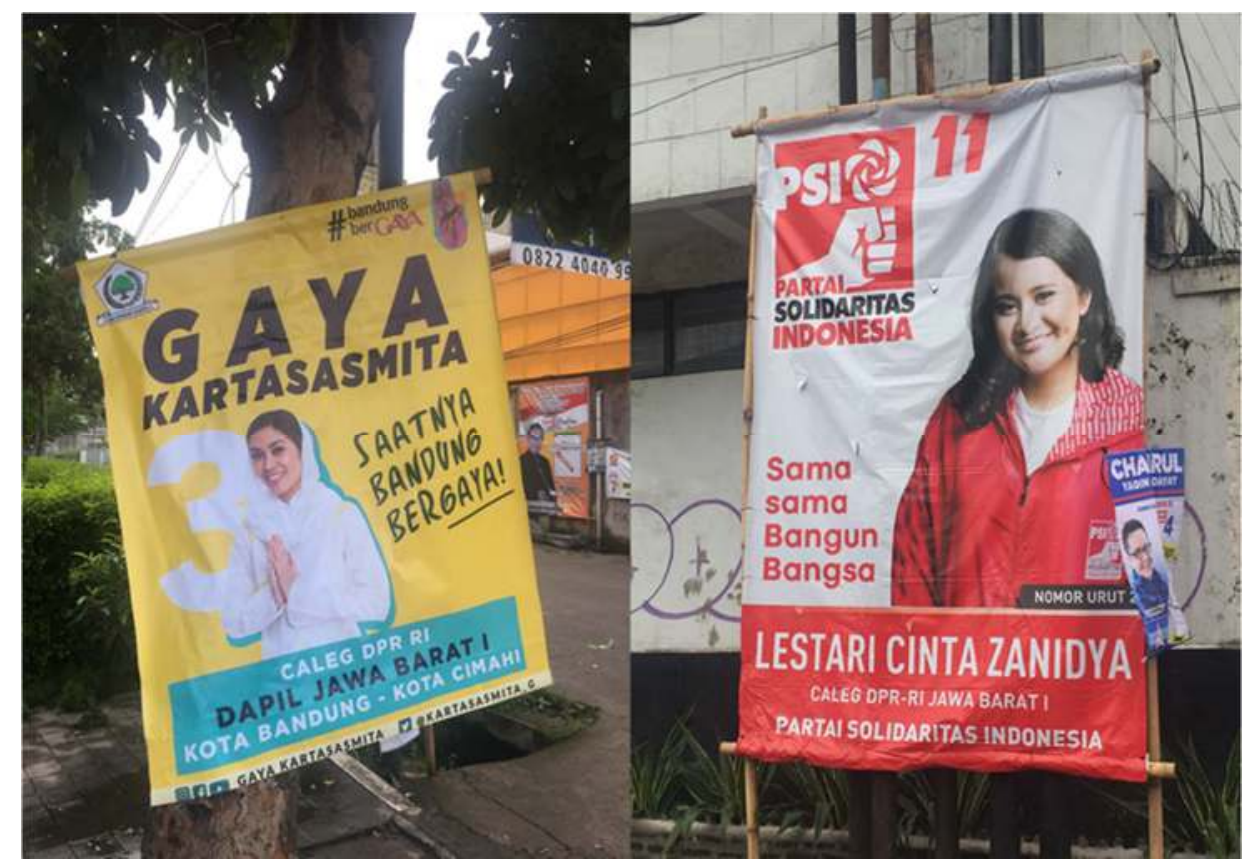

Figure 3. Campaign Props from Gaya Kartasasmita and Lestari Cinta Zanidya. Source: Researcher Doc, 2019.

We found that a "good-design" were coming from a relatively younger participants compared to the three participants that we've discussed earlier. As we see from the example, left Gaya Kartasasmita (GK) from Golkar Party and Lestari Cinta Zanidya (LCZ) from Partai Solidaritas Indonesia (PSI). The campaign props from these two participants were more well design. We can see how they concerned about the aesthetics principles such as harmony, color, typography, participant figure - to the tagline used, "Saatnya Bandung bergaya"/ "It's time for Bandung to be stylish" dan Sama-Sama Bangun Bangsa."/ "Together Building the Nation"

Although the two of them have a well design campaign props compared to the previous one, but it turns out that the two of the GK and LCZ them still do not convey their vision and mission clearly and firmly. In fact, it is the same from the previous one because what is exposed is the participant's face and unclear tagline. Partai Keadilan Sejahtera (PKS) is an interesting well-designed campaign props such as GK's and LCZ's campaign props. Although it is not a clear and firm vision and mission, but the statement is very clear and simultaneous, "if PKS wins the election, the tax for motorbike will be removed and the SIM (driver license) will be valid for lifetime. This statement can and will very attract the attention of the people even though in the parliament this idea/programs from PKS difficult to realize. 


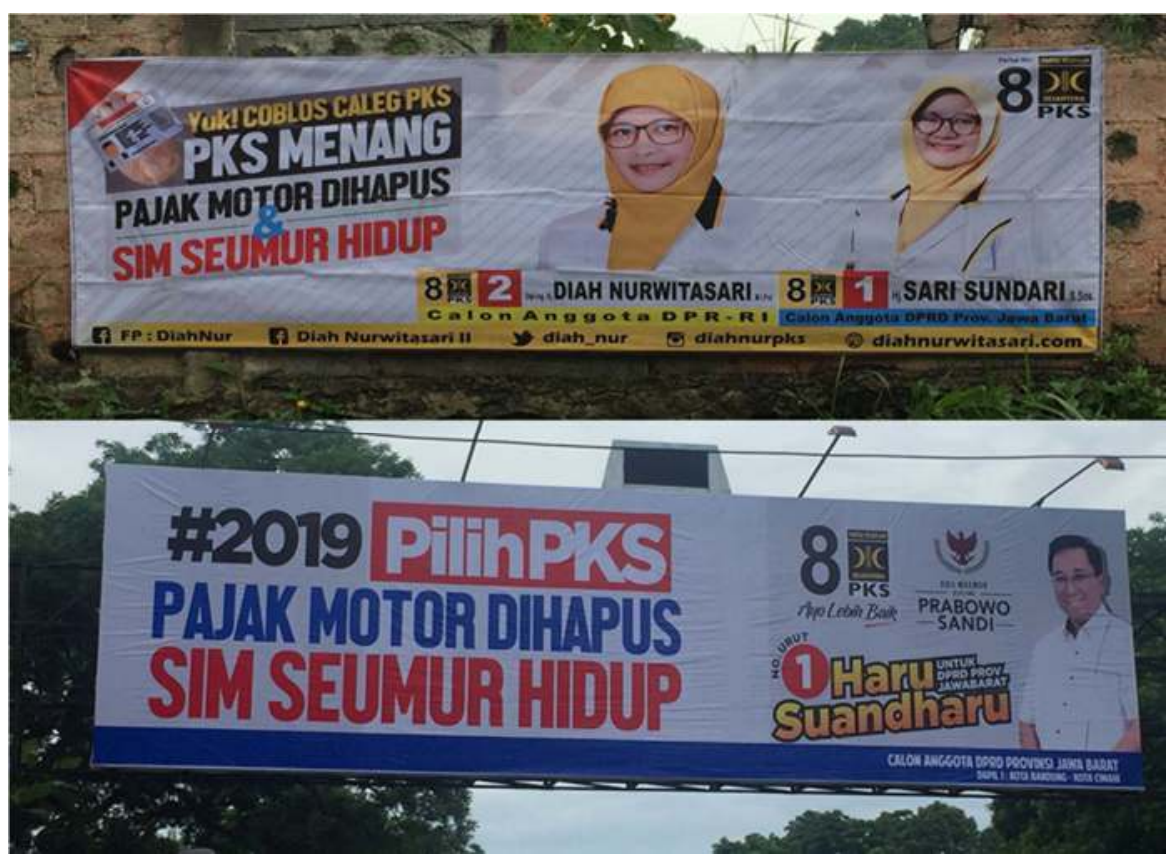

Figure 4. Campaign Props of Diah Nurwitasari, Sari Sundari, dan Haru Suandharu from Partai Keadilan Sejahtera (PKS).

Source: Researcher Doc, 2019.

\section{Conclusions}

For Lefebvre, every community has the same rights to the city as a space. However, in Bandung during the campaign period, the participants seized the rights as a class and aggressively expanded public spaces. KPU has arranged the placement of this campaign props but the hegemonizing of space by these participants were massive by placing as many Campaign props as possible in their constituencies starting from intersections, city parks, trees, and electricity poles. This careless political mind causing a huge amount of 'visual waste' that ignites the aesthetics of the city. It also results in the deprivation of the rights of the people of Bandung over the space in their own city - not to mention after the General Election is completed, what will the Campaign props be done? Of course, this requires further study.

The campaign props design of the participants actually has the same formula even though some younger participants have a fairly good campaign props design. The rest remains the same: exposing faces, names, sequence No's of participants, and National figures or histories attached to and or candidates for the President supported by the Party-or Ormas (Mass Organization) and sports clubs. In the research that we did, almost none of the participants included their clear and firm vision and mission. It was so ironic because they were the candidates for People's Representatives who would represent the voices of the people in Parliament. There are also candidates from PKS who have cohesiveness in their campaign promises that can impact on voters in Bandung, even though as we mentioned, the realization in the parliament will be not an easy as they promised. 
The space and campaign props of the participants in the city of Bandung has a very strong relationship because they produce, reproduce, and construct knowledge continuously through Representational Space and Representational Space. But what the participants did not pay attention is how space and campaign props distributed the experiences and expectations of people in Bandung. As we can see there is no single participant who did substantially 'borrowed' and narrated the Sundanese philosophical concept into their own campaign and campaign props - or they're a huge shifting in our political and society this day.

\section{References}

[1] H. Lefebvre, The Production of Space. New York: Georgetown University Press, 2000.

[2] Komisi Pemilihan Umum Republik Indonesia, Petunjuk Teknis Fasilitasi CAMPAIGN PROPS Bagi Peserta Pemilu 2019. Jakarta: KPU RI, 2018.

[3] H. H. Benny, "Semiotik dan Dinamika Sosial Budaya," Jakarta: Komunitas Bambu, 2011.

[4] A. S. Pamungkas, "Produksi Ruang dan Revolusi Kaum Urban Menurut Henri Lefebvre," Lembar Kebud. Indoprogress, LKIP Ed., vol. 31, 2016.

[5] L. Agung, "Pengantar sejarah dan konsep estetika," Yogyakarta PT. Kanisius, 2017.

[6] A. Setyaningrum, "Estetika Populer dan Identitas dalam Technoculture," Avatar: “Visualizes yourself!," 2009. [Online]. Available: http://kunci.or.id/articles/avatarvisualizes-yourself-estetika-populer-dan-identitas-dalam-technoculture/. [Accessed: 09-Jan-2019].

[7] J. Rancière, The politics of aesthetics. Bloomsbury Publishing, 2013. 